Swarthmore College

Works

10-1-1973

\title{
Control And Freedom: The Structure Of Buddhist Meditation In The Pāli Suttas
}

Donald K. Swearer

Swarthmore College, dsweare1@swarthmore.edu

Follow this and additional works at: https://works.swarthmore.edu/fac-religion

Part of the Religion Commons

\section{Recommended Citation}

Donald K. Swearer. (1973). "Control And Freedom: The Structure Of Buddhist Meditation In The Pāli Suttas". Philosophy East And West. Volume 23, Issue 4. 435-455. DOI: 10.2307/1397716 https://works.swarthmore.edu/fac-religion/119

This work is brought to you for free by Swarthmore College Libraries' Works. It has been accepted for inclusion in Religion Faculty Works by an authorized administrator of Works. For more information, please contact myworks@swarthmore.edu. 


\section{Donald K. Swearer Control and freedom: The structure of Buddhist meditation in the Pāli suttas}

Of all forms of religious practice, none exemplifies Buddhism better than the practice of meditation. Anesaki and Takakusu claim that meditation is ". . . the universal method of mental culture of all Indian religious schools,"1 and Edward Conze writes, "meditational practices constitute the very core of the Buddhist approach to life .... On the way to Nirvāna they serve to promote spiritual development, to diminish the impact of suffering, to calm the mind and to reveal the true facts of existence." 2

This article is an attempt to analyze the structure of Buddhist meditation within the Pāli suttas. Our contention is that this structure is built around two foci-control and freedom. The ultimate aim of Buddhist meditation is freedom from the bondage of attachment to sense objects. This liberating state of being is reached through a process of consciousness control (samādhi) and insight into the real nature of the world (vipassanā). While Theravāda Buddhism tends to distinguish samādhi and vipassana as two separate types of meditation, both aim to achieve enlightenment (sambodha). Furthermore, as this article will show, they may be seen as basically complementary rather than as mutually exclusive methods.

The structure of Buddhist meditation, which emerges from a study of the Pāli suttas, may be depicted by an hourglass figure ${ }^{3}$ :

The path to enlightenment begins with a general awareness and proceeds to a greater and greater degree of consciousness refinement. This process produces decreasing degrees of attachment to the world of sense objects. The jhānas represent a transition from a narrowing of consciousness to its eventual expansion resulting in a condition of "hedonic neutrality," that is, upekkha. In this state the consciousness is totally freed (cetovimutti) from those conditions which qualify ordinary states of mind. It is characterized as immeasurable, nothingness, emptiness, and signless. In this mind-freed state, the knowledge of enlightenment (pañ̃āvimutti) is fully realized. Or, in a better known idiom, one has attained nibbāna.

\section{SATI AND MINDFUL AWARENESS}

The process of meditation and the control of consciousness begin with sati and sampajañna, two practically inseparable terms in the Pāli canon. ${ }^{4}$ They are widely discussed in the Pitakas and later commentaries, and according to

Donald K. Swearer is Associate Professor of Religion at Swarthmore College.

1 Masaharu Anesaki and Junjirō Takakusu, "Dhyana," Encyclopedia of Religion and Ethics, ed. James A. Hastings, vol. 4 (New York: Scribner, 1912), p. 702.

2 Edward Conze, Buddhist Meditation (London: George Allen \& Unwin, 1956), p. 11.

3 For a different model see Conze, Buddhist Meditation, p. 16.

4 The meaning of sati and sampajañna came to be nearly synonymous. Sampajañna is formed from the verb, $p a-j \bar{a} n a \bar{t} i+s a m$ meaning to come to know altogether, hence, to discriminate and comprehend. 
a contemporary Buddhist one of the suttas devoted entirely to an exposition of sati and sampajañ $a$ is among the most highly respected and frequently memorized Buddhist texts in Ceylon..$^{5}$ The Päli word sati is related to Sanskrit smrti, meaning "remembered" or "recollected." In Hinduism the word has come to stand for a body of "remembered" literature (for example, the Epics, sūtras, Purāṇas) in contrast to "revealed" or śruti texts (for example, Samitās, Brāhmanas, Upaniṣads). The term in Pāli has taken on, not only the connotation of something called to mind or remembered, but also mindfulness, intentness of mind, or wakefulness. ${ }^{6}$ Nyānaponika interprets sati as "bare attention" and sampajañna as "clear comprehension."7 Sati as bare attention has a threefold value of helping the mind to know, shape, and liberate itself. ${ }^{8}$ Its knowing function is to analyze the objects of existence through dissection and discrimination and realize the conditioned and conditioning nature of all phenomenal entities. Sati shapes individual's lives by causing reflective action rather than immediate responses. Thus the mind gains a new power and a new freedom from control by habitual action-response. As Nyānaponika expresses it, "Right Mindfulness recovers for man the lost pearl of his freedom snatching it from the jaws of the dragon Time."9 The third value of sati is the freeing of the mind. Paradoxically the control of attention and reflection liberates the mind rather than confining it, for it is sati that produces the insight (vipassana $)$ into the true nature of things. This realization leads to detachment from ordinary preoccupation with the objects and goals of the mundane world.

If sati, or bare attention, is a discipline of the consciousness appropriate to the act of meditation itself, sampajaññ can be understood as the integration of sati with right knowledge ( $\tilde{n} \bar{a} n a)$ or wisdom (pañ $\tilde{a})$. Sampajañna is applied to intentionality and action in particular, and more generally to the awareness that at no time is there an abiding personality or ego behind one's intentions and actions. The sampajañ $a$ dimension of mindfulness emphasizes the fact that the fundamental nonbeingness (anattā) of life is not limited to a serene moment of detached and quiet meditation, but conditions every act and thought of the individual.

Within the Nikāyas there are three suttas devoted entirely to a discussion of sati and sampajañña: the Mahāsatipațthana Suttanta of the Dīgha Nikāya,

5 The Foundations of Mindfulness (Satipațthana Sutta), trans. Nyanasatta Thera (Kandy, Ceylon: The Buddhist Publication Society, 1960).

6 Rhys Davids, T. W. and Stede, The Pali Text Society's Pali-English Dictionary (London: Luzac \& Co., 1959), p. 672 (hereafter cited as Rhys Davids and Stede, Pali-English Dictionary).

7 Nyānaponika Thera, The Heart of Buddhist Meditation (London: Rider \& Co., 1962), p. 30 (hereafter cited as Nyānaponika, The Heart).

8 Ibid., p. 34.

9 Ibid., p. 41. 
the Satipatthāna Sutta of the Majjhima Nikāya and the forty-seventh chapter of the Samyutta Nikaya (Kindred Sayings on the Arisings of Mindfulness). The first Sutta in particular will serve as our guide for a more detailed exposition of sati.

The Mahāsatipațthāna Suttanta is nearly identical with the Satipatțana Sutta of the Majjhima Nikāya with the exception of an exposition of the Four Noble Truths at its conclusion. We are told at the beginning of this dialogue that the only path leading to the purification of beings, of passing beyond grief and lamentation, of the dying out of suffering and misery and the realization of nibbana is the fourfold setting up of mindfulness. ${ }^{10}$ In order to come to grips with the full dimension of sati these four stages of mindfulness must be analyzed.

In the first place, mindfulness demands a control of the body (kāya) which overcomes the desire and misery typical of the world. ${ }^{11}$ This end is accomplished by practices of meditation and concentration. The bhikkhu is to isolate himself, assume a posture of meditation, and practice breathing exercises with a total consciousness of every act so that the bodily organism will be tranquilized. ${ }^{12}$

Mindfulness of the body begins with awareness of respiration. The Buddhist preoccupation with respiration exercises represents a continuity with earlier Indian thought. In the late $R g V e d a$ and the Brähmanas, breath was one of the objects of cosmogonic speculation, the life force through which it was thought the world might have come into being. ${ }^{13}$ Breathing exercises (prānāyāma) also played an important role in Hindu hatha yoga. There the practice was eventually to arrest the movement of inhalation and exhalation. The purpose of breath control in yoga, however, was not merely to gain power over respiratory functions but access to higher states of consciousness. Thus Bhoja's commentary on the Yoga Sütras of Patañjali reads: "All the functions of the organs being preceded by that of respiration-there being always a connection between respiration and consciousness in their respective functions-respiration, when all the functions of the organs are suspended, realizes concentration of consciousness on a single object."14

Breathing exercises as the initiation of sati seem to have a dual function not unlike that in the practice of hațha yoga, namely, to engender control over the body but also to produce an awareness of the real nature of the

10 The Dĩgha Nikãya, 3 vols., eds., T. W. Rhys Davids and J. Estlin Carpenter (London: Luzac \& Co., 1890-1911) 2:290.

11 Ibid., p. 291.

12 Ibid.

13 For example, see $R g$ Veda 10:129.

14 Quoted in Mircea Eliade, Yoga: Immortality and Freedom, trans. Willard R. Trask (New York: Pantheon Books, 1958), p. 55. 
body. As Nyānaponika Thera observes, the mindfulness of breathing is both a subject for "tranquility-meditation" (samathabhāvan̄a) as well as an act used for the development of insight (vipassanābhävanä). ${ }^{15}$

Following the initiation of mindfulness through breathing exercises, the Mahāsatipatthāna Suttanta moves to contemplation of various aspects of the body and its functions. They are in brief: (1) mindfulness of bodily postures (2) contemplation of the parts of the body (3) reflection on the constituent elements of the body, and (4) the so-called cemetery contemplations. Turning first to the mindfulness of bodily postures the bhikkhu is enjoined to contemplate (anupassanā) the body internally and externally as something that comes into being and passes away again. ${ }^{16}$ Furthermore, such contemplation should accompany every act so that ". . . when [the bhik$k h u$ ] is walking, [he] is aware of it thus:-' $\mathrm{I}$ walk'; or when he is standing, or sitting, or lying down, he is aware of it."17 The purpose of the mindfulness of the bodily postures is to gain the knowledge ( $\tilde{n} \bar{a} n a$ ) that he dwells independent, grasping after nothing in the world. ${ }^{18}$ Awareness of bodily postures, therefore, should produce such a total self-awareness in the adept that "In going, standing, sitting, sleeping, watching, talking or keeping silence he knows (sampajāna) what he is doing."19 This total self-knowledge is directed toward two ends: (1) an acknowledgment of the impermanence of the body (its arising and decay) and (2) an independence (anissito) from any attachment to the phenomenal world.

The contemplation of the parts of the body is an extension of mindfulness regarding the body and its functions. It begins with an enumeration of various physical organs and bodily products ranging from hair to the heart to urine. This description of the body and its parts is likened to a bag filled with various kinds of grain which can be separated out and identified: ". . . And a keen-eyed man ... reflects as he pour(s) them out:- 'that's rice, that's paddy, those are beans,' and so forth. Even so, bhikkhus, does a brother reflect on the body from the soles of the feet below upward to the crown of the head, as something enclosed in skin and full of divers impurities."20

Reflection on the parts of the body becomes even more discriminating or analytical, however. From physical parts, the bhikkhu moves his attention to the fundamental bases ( $d h \bar{a} t u$ ) or constituent elements of which the body is composed. In the Theravāda scheme of things these basic elements are

15 Nyānaponika, The Heart, p. 63.

16 The Digha Nikdya, 2:292.

17 The Dialogues of the Buddha (Digha Nikäya), 3 vols., trans. T. W. Rhys Davids and C. A. F. Rhys Davids (London: Luzac \& Co., 1899-1959), 4th ed., 2:329 (hereafter cited as Dialogues).

18 The Digha Nikāya, 2:292.

19 Ibid.

20 Dialogues, 2:330. 
four-earth, water, heat, and air. Mindfulness of the fact that the body is composed of these elements is likened to the butcher who, when he has slain an ox, displays the carcass piece by piece. ${ }^{21}$ There appears to be a twofold purpose behind the development of mindfulness regarding the various parts and constituent elements of the body: (1) the knowledge that no abiding ego exists in the body but only those parts that can be observed and inferred from this observation and (2) the essentially "vile" and impermanent nature of the body.

This second purpose is carried to even greater extremes in the fourth aspect of bodily mindfulness, the cemetery contemplations. Here the bhikkhu is enjoined to contemplate his own body as though it were undergoing ever increasing degrees of decomposition after death. Initially he contemplates a body abandoned in a graveyard which is swollen and turning black and blue; then a body which has been partially eaten by wild animals; and finally a body which has been reduced to a mere heap of bones. ${ }^{22}$ All of these contemplations are symbols of the transient nature of the body. ${ }^{23}$

The second stage of mindfulness is to arrive at the same degree of awareness of the true nature of the feelings (vedana) as was developed by the body. The bhikkhu must be able to distinguish among feelings that are pleasurable (sukha), painful (dukkha), or neutral as well as feelings concerning either spiritual (sāmisa) or material (nirāmisa) things. ${ }^{24}$ All of these types of vedanā are subject to arising and dying away, just as is the body; hence, they are transient, ephemeral. Mindfulness of feelings, consequently, just as mindfulness regarding the body, produces a detachment, an independence from the things of this world.

After subjecting the body (kāya) and the feelings (vedanā) to the kind of objective scrutiny that leads to an understanding of their true nature, the bhikkhu developing mindfulness turns his attention to citta, ". . . the everchanging, ever-active continuance of consciousness, or reacting intelligence"25

21 Ibid., p. 331.

22 The Digha Nikäya, 2:294-297.

23 The preoccupation of early Buddhism with the notion of death offers some interesting possibilities of interpretation other than the rather obvious one given in the text. It might, for instance, be an outgrowth of archaic shamanistic practices, for the shaman is one who above all else is qualified by a knowledge of death. On this point see Mircea Eliade, Shamanism: Archaic Techniques of Ecstasy, trans. Willard R. Trask (New York: Pantheon Books, 1964), p. 509f (hereinafter cited as Eliade, Shamanism). On the other hand, in the dialectic between the sacred and the profane, death plays a very important role. For example, as Van Gennep and others point out, rites of initiation marking a passage from a "profane" state to a "sacred" state are not infrequently signaled by a symbolic recreation of death on the part of the initiate. Arnold Van Gennep, The Rites of Passage (Chicago: The University of Chicago Press, 1961), p. 75f.

24 The Digha Nikàya, 2:298.

25 Dialogues, 2:325. 
and also to dhamma, the ideas, cognizable objects or presentations beyond the stage of mere sensory reaction. ${ }^{26}$ Regarding the citta or conscious thinking process the monk must become aware of its various modes, for example, lustful, dull, intelligent, attentive, or distrait. That this awareness or knowledge of the states of the mind is for the purpose of control is illustrated by the following passage from the Vitakkasanthana Sutta of the Majjhima Nikāya:

... if while the monk is attending to the thought function and form of those thoughts, there still arise evil unskilled thoughts associated with desire and associated with aversion and associated with confusion, ... . that monk, his teeth clenched, his tongue pressed against his palate, should by his mind subdue, restrain and dominate his mind (citta).$^{27}$

Through awareness directed toward the mind, the monk is enabled both to understand and subdue or control the mind or consciousness (citta). It is recognized that citta as well as kāya and vedana comes into being but then passes away. ${ }^{28}$

Regarding the dhamma or ideas, the Mahāsatipațthana Suttanta specifically mentions five groups: (1) the five hindrances (nivarana), (2) the five groups (khandha), (3) the five spheres of sense (äyatana), (4) the seven factors of enlightenment and, (5) the four Aryan truths. All of these groups of dhamma are to be reflected upon with the same scrutiny as body, feelings, and mind with the intent purpose of leading the monk to an independence where he grasps after nothing in the world.

Directing his attention toward the five aggregates (khandha), the bhikkhu considers individually their arising and passing away until in a state of nongrasping he attains to mindfulness. Contemplating the six ayatanas or the internal and external spheres of sense, the monk is made aware that any fetters that bind him to the world are a result of the coming together of the organs of sense and the objects of sense. By his analysis he becomes of the arising and the putting aside of all fetters. Of the seven factors of enlightenment the bhikkhu must grow aware “. . . if they are subjectively present, or absent, and he is aware of how there comes an uprising of any factor not hitherto uprisen, and of how there comes a full development of such factors when it has arisen."29 Finally the Mahāsatipațhanna Suttanta expounds the four Aryan truths, which must also be considered in terms of the same pattern of their arising and passing away.

What in belief is the purpose of sati-sampajañna? In general terms mind-

26 Ibid.

27 The Middle Length Sayings (Majjhima-Nikāya), 3 vols., trans. I. B. Horner (London: Luzac \& Co., Ltd., 1954-1959), 1:155.

28 The Dïgha Nikāya, 2:299.

29 Dialogues, 2:336. 
fulness produces a profound self-awareness. More specifically it is intended to produce a detachment from the world of sense through controlling the sensory inputs, and realizing the fundamental impermanence or nonbeingness (anatt $\bar{a}$ ) of existence. Mindfulness, therefore, offers both a theoretical and practical means for the ". . . realization of that liberating truth of no-self (anatt $\bar{a}$ ), having the two aspects of egolessness and voidness of substance."30 This realization is a "lived understanding." That is, it is arrived at through a carefully graded program in which control of the senses is coupled with an objective, discriminating knowing. The method of mindfulness conjoins psychomental programming, epistemological shifts, and ontological transformation. It lays the groundwork for later developments, in the meditative life.

\section{SAMĀDHI AND ONEPOINTEDNESS}

Samädhi represents a greater degree of control over the mind or conscious-

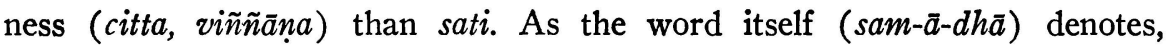
sama $\bar{a} h i$ is a bringing together, a concentration of the mind in contrast to the more general practice of mindfulness (sati). In early Buddhism the important relationship between samädhi as the process whereby one concentrates his thoughts and controls his consciousness and sila or the ethical and moral behavior of the religious man is a general assumption. For our purposes, however, samādhi has crucial implications for the higher goals of the salvation-quest.

In the Subha Sutta of the Digha Nikāya the young Brahman, Subha, asks Annanda to expound the doctrine regarding samädhi. The resulting answer includes elements which overlap with other categories of this exposition, but several points are made which will serve as a basis for our discussion of samādhi.

In the first place the sutta affirms that one practices samädhi by guarding the doors of the senses. ${ }^{31}$ This particular practice is described as follows: when the monk sees an object with his eye he is not grasped either by its general appearance or by its details; he restrains whatever factor might cause the arising of evil elemental reactions; so restraining his sense of sight he attains mastery over his sense of sight. ${ }^{32}$ In a similar fashion he controls his other sense organs: ". . . when he hears a sound with his ear, or smells an odor with his nose or tastes a flavor with his tongue or feels a touch with his body, or cognizes (viñ̃̃aya) a phenomenon (dhamma) with his mind he is not grasped either by the general appearance or the details of it."33 By 
so restraining all of his senses, including the manas or conscious mind, he experiences an unblemished happiness. Having so restrained and guarded all the sense organs so that no element (dhamma) of the mundane world may claim him, the bhikkhu is now mindful (sati) and with clear comprehension (sampajañña). As described in the Subha Sutta, therefore, samādhi begins when the senses are no longer subject to the rule of the objects of sense.

In the Cülavedalla Sutta of the Majjhima Nikāya the layman Visakha asks the nun Dhammadinnā, "What is concentration (samēdhi), what are the distinguishing marks of concentration, what is the development of concentration?"34 To this question the wise nun replies that samädhi is onepointedness of mind (cittassa ekaggat $\bar{a}$ ), its marks the four objects of mindfulness, its requisites the four right efforts and that whatever leads to the increase of these is, in effect, the development of concentration. ${ }^{35}$ This passage points to the close relationship between sati and samädhi. That is, concentration appears to presuppose the four objects of mindfulness. Samädhi, however, goes beyond the awareness of impermanence and sensory detachment produced by sati. It is a refined control of the consciousness, a concentration of the mind to a single point, thereby eliminating all extraneous thoughts. Buddhaghosa in applying the definition cittassa ekaggata to samädhi elaborates as follows: "[samādhi] is the centering of the consciousness and consciousness-concomitants evenly and rightly on a single object." 38 The man of concentrated (samādhi) and one-pointed (ekaggatā) mind, therefore, stands in stark contrast to the profane man who is "empty-headed, frivolous and loose in talk." 37

The Cülavedalla Sutta's exposition of samādhi also says that the requisites of concentration are the four right efforts. The four right efforts are described in various parts of the Nikãyas as follows: checking the rise of evil and wrong states of consciousness not yet arisen; shedding evil and wrong states that have already arisen; encouraging the rise of right states not yet arisen; ensuring that right states which are already there shall be multiplied and developed..$^{38}$ The four right efforts are frequently mentioned as one of the formula truths reported to have been perceived by the Buddha and passed on to his disciples. ${ }^{39}$ While this formula does indeed point to a relationship between samädhi and the production and retention of right constituent states of conscious being, it raises the broader issue of the place of samādhi in a

34 The Middle Length Sayings, 1:363.

35 The Majihima Nikāya, 3 vols., ed. V. Trenckner, R. Chalmers, and C. A. F. Rhys Davids (London: Luzac \& Co., 1888-1899), 1:295.

36 Buddhaghosa, The Path of Purification (Visuddhimagga), trans. Bhikkhu Nanamoli (Colombo, Ceylon: R. Semage, 1956), p. 85.

37 The Book of Gradual Sayings (Ang ttara-Nikäya), 5 vols., trans. F. L. Woodward and E. H. Hare (London: Oxford University Press, 1932-1936), 5:65.

38 The Majjhima Nikāya, 2:11.

39 For example, see The Digha Nikaya, 2:120. 
variety of conceptual structures illustrative of an enlightened state of mind. For instance all of the five iddhipa adas, the paths to the attainment of supranormal powers, are dependent on samādhi. ${ }^{40}$ The five forces (indriyāni) or organs of spiritual sense include samādhi which is described by one Buddhist scholar as "the dominant faculty, which brings about concentration of thoughts and makes the adept rise higher and higher in meditations." ${ }^{11}$ Samādhi is also the sixth of the seven factors leading to enlightenment, ${ }^{42}$ and it has already been pointed out that concentration is one of the three major divisions of the Noble Eightfold Path. On the basis of the crucial role played by samādhi in the formulae cited, it is arguable that concentration of mind is the necessary step to the attainment of a higher truth and the powers accompanying it.

The Buddhist adept who chooses the way of $s a m \bar{a} d h i$ begins his religious quest with a general awareness of the nature of the self and reality but must move beyond the state of objective detachment produced by this mindfulness. He must progress to a unity of concentration which eliminates the flow of sensory material into his conscious mind. By such a concentrated effort he is able to rise to higher forms of apperception, to a mystic intuition of a reality veiled to ordinary perception..$^{43}$

\section{JHĀNA, STAGES TO THE ULTiMATE}

Buddhist meditation progresses from samādhi to $j h \bar{a} n a$, or from concentration and onepointedness to the gradual expansion of the consciousness to hithertofore unexperienced dimensions. In the Păli Suttas, jhāna is often found as part of the formula of the four jhanas, where it is translated as mental absorption or trance. By carefully analyzing this formula and the contexts in which it occurs, the significance of $j h \bar{a} n a$ in relationship to the control of consciousness and saving-knowledge will become clear.

In the Brahmajāla Sutta a discussion of the four jhänas occurs within the context of the question, "How may the self or soul (atta) attain to the highest Nibbāna in this visible world?" It is in answer to this question that an explication of the four jhānas is set forth.

40 The five iddhipadas are resolution (chanda), effort (viriya), consciousness (citta), and investigation (vīmamsā). The Dĩgha Nikäya, 3:77.

41 Nalinaksha Dutt, Early Monastic Buddhism, rev. ed. (Calcutta: Oriental Book Agency, $1960)$, p. 248.

42 The seven factors or limbs of enlightenment (sambojjhanga) are: sati, dhammavicaya, viriya, pīti, passaddhi, samädhi, and upekkhä.

43 The process of mental training became greatly elaborated in the scholastic or Abhidhamma period of Theravāda Buddhism. Nalinaksha Dutt provides an excellent discussion of the various forms of samädhi (as represented in particular by the Vissuddhimagga) in chapter 7 of Early Monastic Buddhism. 
In this sutta it is accepted as an a priori condition of phenomenal existence that the self is subject to kamma or sensuous desires. It is also the case that sensuous desires are characterized by impermanence (anicca). Phenomenal existence, therefore, necessarily involves suffering since sensory pleasures are constantly subject to change. The only way one can hope to achieve happiness and joy (pitisukha) is by cutting off kama. In the first jhāna this state is accomplished by detachment (viveka) accompanied by reflection and investigation (vitakka-vicāra). In order to understand this $j h \bar{a} n a$ these three terms must be studied in some detail.

The term viveka has a threefold significance: a physical separation from the world in the sense of "seclusion"; an intellectual separation in the sense of "discrimination"; and an ethical separation in the sense of the mind (citta) "being separate from the world."44 For instance, in the Mahāsuñnatā Sutta the Buddha tells Ānanda that a bhikkhu who delights in society cannot enjoy well-being or emancipation of mind (cetovimutti) but that such happiness demands renunciation, solitude, and enlightenment (sambodha). ${ }^{45}$ The Buddha claims that as a Tathägata he has reached such a state of isolation (viveka) by dismissing thoughts of all attendant phenomena and by developing and dwelling in a state of emptiness (suñnatā). ${ }^{46}$ The sutta goes on to say that a monk who likewise desires to develop and dwell in inward emptiness should calm, tranquilize, focus and concentrate his mind inwardly. ${ }^{47}$ This sutta clearly indicates that viveka implies both a physical separation from the delights of ordinary worldly intercourse as well as an isolation of the mind (citta). It is interesting to note that the resultant separation is described as a condition of inward emptiness (suñ $\tilde{n} a t \bar{a}$ ) since in the later Mādhyamika tradition the perspective on this important term will shift from a psychophysical emphasis to an ontological one.

In the Nalakapāna Sutta of the Majjhima Nikäya, viveka is described in terms of separation from sensuous desires and from the evil constituents of being. This separation is said to result in the attainment of joy and happiness. The Tathāgata who has reached such a state has overcome the attachments to the mundane world known as the asavas, which produce the suffering of "birth, old age and death." 48 Viveka, then, means a detachment from the world of sense with its accompanying desires and kammic resultants of rebirth.

The terms vitakka and vicāra should be taken together. In fact T. W. Rhys Davids contends that by examining the use of these two words in earlier

44 The Dialogues of the Buddha, 1:84 (see the footnote).

45 The Majihima Nikāya, 3:110.

46 Ibid., 3:111.

47 Ibid.

48 Ibid., 1:464. 
and later works, one concludes that they once had synonymous meanings. ${ }^{49}$ They came to have slightly different intentions, however, with vitakka referring in particular to initial thought or observation and vicāra denoting continuing or sustained investigation and reflection. Together they are used to indicate ". . the whole of the mental process of thinking."

In the Upakkilesa Sutta of the Majjhima Nikāya both vitakka and vicāra are related to concentration (samädhi). The Buddha is recorded as saying that by developing samädhi in several modes beginning with vitakka and vicāra, he gained the knowledge ( $\tilde{n} \bar{a} n a$ ) and the vision (dassana) that his final liberation (vimutti) was assured. Vitakka and vicāra, therefore are important to the concentration (samädhi) of one's thoughts and act as one of the first steps toward the attainment of the apperception (dassana) of ultimate reality. They share with viveka the characteristics of directing the individual away from mere sensory reality. Thus in the Dasuttara Suttanta of the Digha Nikāya the eight thoughts (vitakka) of the great man (mahāpurisa) include the limitation of desires, detachment, and mental concentration. ${ }^{51}$ As we shall see, however, vitakka can become dangerous. As the Sakkapañha Suttanta of the Dīgha Nikāya points out, vitakka can become a mental preoccupation which causes desire (chanda), ${ }^{52}$ the root of attachment to the mundane world. ${ }^{53}$

In sum, the first $j h \bar{a} n a$ is depicted primarily as a condition of detachment. It involves a physical, intellectual, and ethical separation from the phenomenal world. An important phase of the development of the concentration necessary to acquire the first jhäna is careful thought and analysis of one's self and the surrounding world.

The second $j h \bar{a} n a$ is achieved when observation and investigation (vitakka and vicāra) are suppressed. In this stage these two mental functions are said to be olärika or gross, implying that they are necessarily involved in the empirical world. The second jhäna is characterized by joy and happiness (pitisukha), born not of viveka or detachment but of samädhi, translated by Rhys Davids in this passage as "serenity." 54 This state is further characterized by a tranquil inner nature and a concentrated mind or heart. ${ }^{55}$

Just as the first jhāna was labeled gross (olārika) since it involved vitakka and vicāra, the second acquires the same rubric because it is characterized by

49 Rhys-Davids and Stede, Pali-English Dictionary, p. 620.

50 Ibid.

51 The Dialogues of the Buddha, 3:261.

52 In this particular case, chanda or excitement is nearly identical in meaning with tanha, thirst or craving.

53 The Digha Nikāya, 2:277. Dialogues, 2:311.

54 Dialogues, 1:50.

55 The Digha Nikäya, 1:37. 
joy (piti) and an exhilaration of the heart. ${ }^{56}$ The qualities which are found in one who attains to the third jhāna are equanimity (upekkhā) and mindfulness (sati), "self-possession" (sampajāna), dispassion (virāga), and an abiding happiness. Finally in the fourth jhäna the attention of the heart on happiness is transcended as is a concern with its opposite, $d u k k h a$ or suffering. ${ }^{57}$ Similarly the polarity of somanassa and domanassa or mental distress is overcome. The last jhäna is, therefore, composed of pure equanimity and mindfulness (upekkhāsatiparisuddhi) ${ }^{58}$ and is "a state where some maintain the complete happiness, in the visible world, of a living being."

The fourfold jhāna formula appears again in the Sāmaññaphala Sutta, the discourse on the fruits of the life of a samana or recluse. In this sutta the discussion of the jhanas is preceded by an overcoming of the five hindrances or nivaranas and is followed by the acquisition of supranormal powers or iddhi and abhiñ̃ $\bar{a}$ (supranormal knowledge) as well as the overcoming of the asavas. To understand more fully the role of jhana within the scope of Buddhist soteriology, we shall examine in some detail the most important of the concepts in this sutta, namely, nīvarana, iddhi, abhiñña, and āsava.

The classical formula of the five nivaranas ${ }^{60}$ as found in the Sämaññaphala Sutta and elsewhere in the Nikāyas (for example, Dīgha III, 49) is described as follows: (1) coveting the world, (2) malevolence and the desire to injure, (3) stolidity and slothfulness, (4) excitement and misdeeds and (5) wavering or doubt. ${ }^{61}$ One must overcome these hindrances so that in each case the mind may be purified. Separated from sensuous desires and evil elemental impulses the samana is enabled to enter into the sequence of the four jhanas previously described. ${ }^{62}$ With the exception of the fifth nivarana the concern of this formula is clearly with those emotions which tend toward unreflective involvement in the phenomenal world. As Saimyutta Nikäya 5:83 puts it, the nivaranas are conducive ". . . to the still more becoming and growth thereof."63 Involvement in the becoming of the phenomenal world supposes lack of insight or ignorance described as blindness and loss of sight. One who has not overcome the nivaranas obviously is unable to acquire any degree of knowledge beyond that granted through the agency of the senses in dependence on the empirical world.

56 Ibid.

57 Ibid., $1: 37-38$.

58 Ibid., $1: 38$.

59 Dialogues, 1:51.

${ }^{60}$ Nivarana is the Sanskrit nis + varana literally meaning not choosing or unable to choose and, hence, an obstacle or hindrance.

61 The Dìgha Nikāya, 1:71.

62 Ibid., 1:73.

63 The Book of Kindred Sayings (Samyutta-Nikāya), 5 vols., trans. C. A. F. Rhys Davids and F. L. Woodward (London: Oxford University Press, 1917-1930), 5:70. 
The Sämañ̃aphala Sutta makes clear, however, that one who passes through the jhanas transcends an ordinary involvement in the phenomenal world exemplified by the nivaranas. Through attaining the four jhannas the consciousness or mind (citta) is made pure (parisuddha), freed from blemish, devoid of evil (kilesa), ${ }^{64}$ stable and immovable. ${ }^{65}$ The citta is thereby freed to direct itself toward the "insight that comes from knowledge."66 This insight is simply that this body ( $k \bar{a} y a)$ has a form ( $r \bar{u} p a)$ composed of the four great elements; that it is a result of a human birth; that it is perpetuated by partaking of foods; that it is impermanent and subject to dissolution and disintegration; and that consciousness itself (viññana) depends on the body and is bound up with it. ${ }^{67}$ With the citta purified and collected, the samana has the mental power to be able to create (maya) with it another body (aññ $k \bar{a} y a)$ than the body subject to the frailties described above. As the text describes this process it is ". . . as if a man were to pull out a reed from its sheath. He would know: "this is the reed, this the sheath. The reed is one thing, the sheath another. It is from the sheath that the reed has been drawn forth.' And similarly were he to take a snake out of its slough, or draw a sword from its scabbard." 68

The notion of manomaya or mental power has significant possibilities for this study; however, on the basis of the Pāli texts it is difficult to arrive at a specific interpretation. In general the term denotes being made or formed by the mind, particularly as though magically made. ${ }^{69}$ For example, the Brahmajāla Sutta refers to the evolution of the world system to the point where most beings have been reborn in the "World of Radiance" and "there they dwell made of mind (manomaya), feeding on joy, radiating light from themselves, traversing the air [and] continuing in glory . . . "70 A similar association of manomaya with a heavenly realm is found in the Apannaka Sutta of the Majjhima Nikāya. There it is stated that the corporeal gods are a product of manomaya.71 The two passages cited above clearly refer to the

64 The word, kilesa, along with other terms such as the nivarana, tanh $\bar{a}$, the assava, etc., has reference to unthinking involvement in the phenomenal or profane world. Kilesa literally means stain, soil, impurity and comes to stand for sensuous desires, passions, etc. "Its occurrence in the Pițakas is rare; in later works, very frequent, where it is approx. tantamount to our terms lower or unregenerate nature ...." Rhys Davids and Stede, Pali-English Dictionary, p. 216.

65 The Digha Nikãya, 1:76.

66 Dialogues, 1:86.

67 The Digha Nikāya, 1:76. We find here a standard description of the body. Consciousness (viñ $\tilde{n} a n a$ ) in this instance indicates the five senses or the entire emotional and intellectual process. See Dialogues, 1:87, notes 1 and 2.

68 Dialogues, 1:88.

${ }^{69}$ Rhys Davids and Stede, Pali-English Dictionary, p. 521.

70 Dialogues, 1:30. The Digha Nikâya, 1:17.

71 The Majjhima Nikaya, 1:410. 
magical power of the mind by relating manomaya to the mythological realms of Buddhism. Indeed, manomaya's earliest meaning may have been magically oriented-the notion that mano was responsible for the attainment of heavenly rewards of some form or another; however, we find that manomaya comes to assume both ethical and ontic connotations.

For instance, the Dhammapāda opens with the following two verses:

Mind is the forerunner of (all evil) states. Mind is chief ; mind-made are they. If one speaks or acts with wicked mind, because of that, suffering follows one, even as the wheel follows the hoof of the draught-ox.

Mind is the forerunner of (all good) states. Mind is chief; mind-made are they. If one speaks or acts with pure mind, because of that, happiness follows one, even as one's shadow that never leaves.

In this passage the ethical and the ontic are definitely related in terms of mind, that is, the mind appears as the center point. It has, as it were, the power to create the "self." The ethical dimension stems from this fact. If the mind is ignorant and impure, one will suffer; if, on the other hand, the mind is enlightened and pure, one will attain happiness.

Having overcome the five hindrances, attained the four mental absorptions and the power of manomaya, the samana now acquires $i d d h i$ or supranormal power, and abhiñna or supranormal knowledge. The term iddhi is of preBuddhistic origin. In different contexts it may be used in the Pāli texts to describe the potency of a king, a rich noble, a hunter, etc. ${ }^{72}$ In the Sāmaññaphala Sutta, eight modes of $i d d h i$ are mentioned: (1) the power of becoming one or many, (2) the ability to become invisible, (3) passing through objects such as walls and hills, (4) penetrating through solid ground, (5) the power to walk on water, (6) traveling cross-legged in the sky, (7) touching the moon and the sun, (8) reaching Brahmā heaven. ${ }^{\mathbf{7 3}}$

The above listed iddhis acquired by the Buddhist adept have striking similarities with the archaic phenomenon of shamanism. ${ }^{74}$ The coincidence of characteristics between these two religious practitioners has been studied by Mircea Eliade in his monograph, Shamanism: Archaic Techniques of Ecstacy. ${ }^{75}$ In particular he points to the "identity in expression" between the superhuman experiences of the Buddhist yogin and the archaic symbolism of ascent and flight found so frequently in shamanism. ${ }^{\mathbf{7 0}}$ Symbols of ascent and flight are especially important since they illustrate the ecstatic experience at which

72 Rhys Davids and Stede, Pali-English Dictionary, p. 120.

73 Dialogues, 1:88-89.

74 Eliade notes that the word, shaman, is derived through the Russian from the Tungusic, "saman." Some scholars, however, have derived the term from Pāli. See Eliade, Shamanism, p. 495.

75 See chapter 11, "Shamanic Ideologies and Techniques Among the Indo-Europeans," in Eliade, Shamanism.

76 P. 409. 
shamanism aims. The shaman through the medium of this experience obtains a superhuman state of being enhancing him with such powers as flight, especially for the purpose of reaching otherworldly realms. The magical aspect of this power is well illustrated by our particular text, which specifically indicates that prior to the acquisition of $i d d h i$, the samana has exercised the power of manomaya, the "magic" of his mind, in order to create "another body." It would appear that the iddhi which follow are powers of that "other body" created as a result of passing through the four $j h \bar{a}$ nas.

The possible shamanistic and, hence, magically oriented origin of $i d d h i$ is furthered by what appears to be a growing suspicion on the part of early Buddhism toward the public display of paranormal or superhuman psychic powers. In the Kevaddha Sutta of the Digha Nikāya the Buddha is represented as warning against the use of magical wonders because they might be confused with the use of magical charms practiced in Gandhära. ${ }^{77} \mathrm{He}$ is made to say, "It is because I perceive danger in the practice of mystic wonders, that I loath, and abhor, and am ashamed thereof." "I8 In the Vinaya Pitaka it is stated that a monk should not display psychic powers before the laity beyond the powers of ordinary men. ${ }^{79}$ The Sampasādanīya Sutta of the Dīgha Nikāya makes it clear that there are indeed two types of $i d d h i$, one which is termed ignoble and the other noble. ${ }^{80}$ The ignoble are those powers discussed above in the Samañnaphala Sutta and elsewhere in the Nikāyas. ${ }^{81}$ In the Sampasādaniya Sutta the iddhis are labeled ignoble since they are concomitant with mental intoxicants and worldly aims. ${ }^{82}$ In other words, it is possible to employ the fruits of the $j h \bar{a} n a$ or the $i d d h i$ in such a manner that the mundane world, rather than being transcended, becomes even more attractive and one's involvement within it is deepened even further. Iddhi produced through manomaya may become the occasion of a descent into the actual or phenomenal world rather than ascent into the real or noumenal.

In contrast to the ignoble powers, all of which involve some superhuman power, the Sampasādaniya Sutta describes the noble powers as follows: "When a bhikkhu can, if he so desire, remain unconscious of the disgust amid what is disgusting; or conscious of disgust amid what is not disgusting; or unconscious of disgust amid what is both disgusting and the opposite; or, avoiding both that which is disgusting and the opposite, should remain indifferent to them as such, mindful and understanding." 83 As should be expected, the

77 The Dialogues of the Buddha, 1:278.

78 Ibid.

79 The Book of Discipline (Vinaya-Pițaka), 5 vols., trans. I. B. Horner, Sacred Books of the Buddhists (London: Luzac \& Co., 1940-1952), 2:112.

80 The Digha Nikaya, 3:112.

81 See the Kevaddha Sutta.

82 The Digha Nikâya, 3:112.

83 Dialogues, 3:107. 
noble $i d d h i s$ overcome the mental intoxicants (a asavas) and the worldly aims instead of becoming further embroiled in them. Rather than representing the superhuman or the magical, Aryan powers stand for control of sañ $\bar{a}$ or perceptions and lead to an indifference (upekhaka) toward the disgusting and the nondisgusting, those polarities which qualify our perception of the phenomenal world.

The transformation of $i d d h i$ from an archaic, magical meaning is further illustrated by the Janavasabha Suttanta of the Digha Nikāya describing the four ways in which $i d d h i$ is developed. They are: concentration and effort with desire (chanda-samādhi), concentration and effort with energy (viriya-sa$m \bar{a} d h i$ ), concentration and effort with a "dominant idea" (citta-samādhi), concentration and effort with investigation (vimamsā-samādhi). ${ }^{84}$ Here we find a progression not to a state of ecstasy leading to powers of invisibility and flight, but rather a progression from desire (chanda) to investigation ( $v \bar{\tau}-$ mams $\bar{a}$ ), or from motivation and effort to a more refined and sophisticated use of the mind. It appears that $i d d h i$ as the fruit of $j h \bar{a} n a$ becomes, rather than supernatural powers acquired in shamanistic trance, a discriminating understanding (vimams $\bar{a}$ ) of the phenomenal world engendering a detached objectivity (upekhaka) in the face of the polarities of impure/pure, loathsome/ nonloathsome, disgusting/nondisgusting typical of the phenomenal or mundane world.

In addition to $i d d h i$, the Sãmaññaphala Sutta indicates that other powers are acquired by the samana who has overcome the nivaranas and acquired the jhānas. These powers are said to be the heavenly or divine ear; discernment of various types of minds or citta; knowledge of previous existences; the heavenly or divine eye with which the adept ". . . sees beings as they pass away from one form of existence and take shape in another . . ."85 These supranormal powers eventually developed into a stereotyped list of six $a b$ hiññas (higher knowledge). They appear in the Dasuttara Suttanta of the Digha Nikāya as follows: (1) the iddhis in their various modes described above; (2) "deva-hearing" by which the adept "hears sounds both heavenly and human, far and near"; (3) a mind that ". . . understands the minds of other beings, other persons..."; (4) an ability to recall to mind ". . . the various temporary states as he lived in days gone by ..."; (5) "deva-sight" by which "he discerns the pageant of beings faring according to their deeds"; (6) the realization and knowledge of the extinction of the "intoxicants" (ãsavas) and the attainment of freedom. ${ }^{86}$

We can discern in this list an amalgam of two different types of abhiñ $\tilde{a}$. In the first instance there is the type illustrated by the occurrence of the 
supranormal powers in the Sāmaññaphala Sutta. There the abhiññãs are acquired as the result of jhanna through the power of manomaya. In particular, however, abhiñ $\tilde{n} \tilde{a}$ seems to express a psychic or mental power in contrast to the extraordinary physical power of the $i d d h i s$. For example, the heavenly ear and the divine eye would appear above all else to indicate a heightened mode of perception enabling the adept to arrive at a supranatural knowledge bordering on omniscience. Thus $i d d h i$ and abhiñ $\tilde{n} \bar{a}$ seem to complement each other, the one pointing to physical power, the other to mental power. It is just such a mutually supporting role, for example, that $i d d h i$ and abhiñña play in the Akankheyya Sutta of the Majjhima Nikāya. ${ }^{87}$

There is, on the other hand, another type of abhiñ $\tilde{n} \bar{a}$ in the Dasuttara Suttanta list, a "higher knowledge" of the destruction of all attachments to the mundane and of the realization of ultimate reality or nibbāna. This aspect of the abhiñ $\tilde{a} \tilde{a}$ is found in the Samyutta Nikāya, where they are preceded by the "middle path" and followed by enlightenment and nibbanna. ${ }^{88}$ Or, again in the Anguttara Nikãya where it is said that the abhiññas lead to full emancipation, ${ }^{89}$ and the $D \bar{\imath} g h a$ where we find that they are contrary to priestly superstitions and vain (sophistical) speculations. ${ }^{90}$ In other words, abhiñ $\tilde{n}$, at this level, is insight into the truth claims of Buddhism regarding the nature of reality. It may be that the two seemingly different types of abhiñ $\tilde{n} \tilde{a}$ represent a synthesis of a more popular and "primitive," magically oriented tradition with the more sophisticated, ethically oriented tradition of the priests. It is difficult to assert, as the Päli Text Society Dictionary does, that the more magically oriented understanding of abhiñ $\tilde{a} \tilde{a}$ is later. ${ }^{91}$ Perhaps all that can be safely said is that in the Nikayyas the two traditions came to be amalgamated. That is to say, it was expected that as a person gained detachment from the phenomenal world he not only gained a "higher knowledge" (abhi-jña $\bar{a}$, but supranormal powers (iddhis) as well.

Having destroyed the nivaranas, attained the jhanas, the iddhis, and abhiñ-

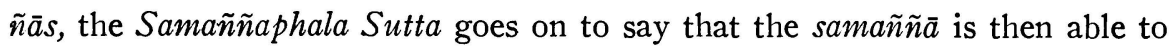
destroy the "deadly floods" or "intoxicants" (äsavas) that are part of the attachment of the profane man to the mundane world. In this sutta the asavas are enumerated as kāma (sensual desire), bhāva (becoming or desire for future life), and avijja (ignorance of the four noble truths) ${ }^{92}$ One of the most famous passages referring to the intoxicants is contained in a formula repeated throughout the Nikāyas, the Mahäparinibbāna Sutta in particular.

87 The Majjhima Nikāya, 1:33.

88 The Book of Kindred Sayings, 5:357.

89 The Book of Gradual Sayings, 4:179.

90 The Dìgha Nikāya, 3:131.

91 Rhys Davids and Stede, Pali-English Dictionary, p. 64.

92 The Dìgha Nikâya, 1:83. 
It illustrates the interrelationship of conduct (sìla), concentration (samādhi), and understanding ( $p a \tilde{n} \tilde{n} \bar{a})$ in overcoming the $\bar{a}$ savas. After affirming that concentration must be accompanied by right conduct and understanding by concentration, the passage concludes that the mind (citta) of the individual surrounded by a profound understanding ( $p a \tilde{n} \tilde{n} \bar{a})$ of the nature of reality will be freed (vimuccati) from being "poured out" (assava) into the mundane world through sensual desires, the wish for a life of continual becoming, false views, and ignorance of his true state of being. ${ }^{93}$

The assavas, as do the nivaranas, serve to clarify that from which the jhãnas free a man. Fundamentally it is the mundane, specifically as the world of sensuous desire, becoming, anger, worry, dullness, stupidity ; or, in other words, ignorant, unthinking involvement in and attachment to the empirical world. The jhannas represent stages by which an individual attains a power of mind

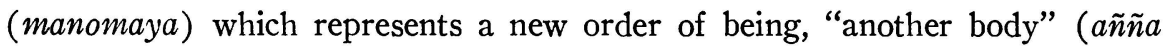
$k \bar{a} y a)$ as the text states it. This new being is graphically illustrated by certain powers the texts describe partially in the terms of a popular, magical tradition and partially in terms of the higher knowledge represented by the Buddhist analysis of existence. We may conclude that the $j h \bar{a}$ nas preserve two types of knowledge in relationship to the salvation quest: ecstasy and a mode of knowledge characterized by vimmamsāa, vitakka, and vicāra or more rational and discriminating forms of thinking. Knowledge as power, then, comes to take on a rather particular meaning. It is power over the world of becoming and change, but it is also the power of new being.

\section{UPEKKHĀ AND THE UNLIMITEDS}

We have seen in our discussion of $j h \bar{a} n a$ that $u p e k k h \bar{a}$ (equanimity) appeared in the third stage and that in the fourth there remained only sati (mindfulness) and upekkhā. Having discussed the former term, we now turn to an examination of $u p e k k h \bar{a}$. The word $u p e k k h \bar{a}$ is derived from the Sanskrit root $i k s$, meaning to gaze or look at, plus the prefix $u p a$; hence, the word literally means to overlook or neglect. ${ }^{94}$ Its meaning is extended, however, to denote patience, equanimity, or indifference. The Pãli Text Society Dictionary defines $u p e k k h \tilde{a}$ as, "hedonic neutrality or indifference, the zero point between joy and sorrow." 95 A. B. Keith notes that upekkha, as a quality of the third and fourth $j h \bar{a} n a$, does not actually connote a hedonistic sense of indifference but rather an intellectual neutrality. Thus, upekkha, at least in its jhānic context, is an impartial tolerance in regard to all mental states.96

93 Ibid., 2:81.

94 Monier-Williams, A Sanskrit-English Dictionary, p. 215.

95 Rhys Davids and Stede, Pali-English Dictionary, p. 150.

${ }^{96}$ A. B. Keith, Buddhist Philosophy in India and Ceylon, 4th ed. (Varanasi: Chowkhamba Sanskrit Series Office, 1963), p. 126. 
A broad survey of the uses of $u p e k k h \bar{a}$ in the Theravāda tradition is given by Edward Conze as follows: (1) neutral feelings which are neither pleasant nor unpleasant, (2) an attitude of "serene unconcern" or sameness of thought arising from the practice of concentration or jhäna, (3) the final stage of worldly wisdom just prior to reaching the Path when evenmindedness toward all conditioned beings is achieved, (4) the equanimity of the Arahant who retains a natural state of purity, (5) the equanimity of the Arahant as contrasted with the dull indifference of ignorant men, and (6) an attitude or impartiality providing an antidote to ill will and sensuous greed. ${ }^{97}$

In the Nikāyas themselves we discover that $u p e k k h \bar{a}$ is used frequently in the formula of the four brahma vihäras or the abodes of brahmā. The brahma vihäras are four "states of mind" that result, after death, in a rebirth in the heavenly worlds of $b r a h m a \bar{a} .{ }^{98}$ There is disagreement among Buddhist scholars as to the origin of the brahma vihäras. T. W. Rhys Davids contends that they were almost certainly exclusively Buddhist, ${ }^{99}$ whereas E. J. Thomas believes they show a direct connection with Brahmanical practices since they occur in the Yoga Sütras. ${ }^{100}$ Regardless of origin, however, the brahma vihäras are important as modes of heightened awareness, although they are not in themselves the highest goal of nibbāna. ${ }^{101}$

Another term used in the Nikāyas to define the brahma vihäras is appamañ $\tilde{a}$ or "infinite feelings." 102 This term is applied to these states of mind or categories of consciousness dealing with mind expansion. Mahasudassana Suttanta of the Digha Nikāya reports the following attainments of "the Great King of Glory" after reaching the fourth jhäna: "And he let his mind pervade one quarter of the world with thoughts of love; and so the second quarter and so the third and so the fourth. And thus the whole wide world, to pervade with heart of love, far-reaching, grown great, and beyond measure, free from the least trace of anger or ill will."103 And in a similar fashion he pervaded the whole world with a consciousness of compassion, sympathetic joy, and equanimity. The brahma vihāras in general and $u p e k k h \bar{a}$ in particular represent, if you will, universal states of consciousness. They are one of the somewhat paradoxical outcomes of the process of meditation and the control of the mind which has been described in the Nikãyas, a process that becomes even more

97 Conze, Buddhist Thought in India, pp. 89-90.

98 The four brahma vihäras are: love (mettā), compassion (karunāa), sympathetic joy

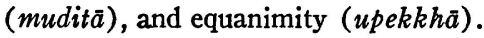

99 Dialogues, 1:298.

100 Edward J. Thomas, The History of Buddhist Thought, 2d ed. (London: Routledge \& Kegan Paul, 1951), p. 50.

101 Ibid.

102 Appamañ ña corresponds to the Sanskrit prāmänya + the prefix, $a$, literally meaning "not."

103 Dialogues, 2:219. 
refined in a later period. This outcome of Buddhist meditation is seemingly paradoxical in that the progression from sati to samädhi, and even into the jhānas, was primarily a narrowing down of the consciousness. But the narrowing of the consciousness was for the purpose of its ultimate liberation. The refinement of the mind was important primarily for the elimination of attachment to the objects of sense and concomitantly to develop such mental control that the mind developed the power to construct a new reality (manomaya). That is to say, the purpose of meditation in the Nikāyas is to free the mind from dependence on sensory objects so that it can be expanded to realities which defy empirical definition. Upekkhā, therefore, becomes the last element in the seven factors of enlightenment and is a characteristic shared by both Arahants and buddhas.

Perhaps the significance of the difference in consciousness implied by $u p e k$ $k h \bar{a}$ and ordinary states of consciousness can be best demonstrated by referring to two Nikāya texts. The Salāyatanavibhanga Sutta of the Majjhima Nikāya lists six indifferences $(u p e k k h \bar{a})$. A worldly indifference is ". . . the indifference on seeing a thing which appertains to the ignorant and foolish average man ... such indifference . . . fails to transcend the thing seen . . ."104 By way of contrast the indifference of renunciation arises when ". . . on discerning the transitory nature of things seen and their mutability, instability and annihilation, indifference arises from causal understanding." 105 Upekkha denotes, therefore, a transcendence of the thing seen.

Assuming that meditation frees the mind from dependence on the mundane world, to what is it freed? The answer must of necessity be in abstract terms, and the person who is looking for a concrete definition of the knowledge of ultimates is bound to be disappointed; however, one answer given by the Nikāyas is found in the Mahāvadella Sutta of the Majjhima Nikāya. There, in a conversation between Säriputta and Kotthita the Great, Säriputta discusses four "freedoms" of the mind (cetovimutti): appamānā (immeasurable), $\bar{a} k i \tilde{n} c a \tilde{n} \tilde{n} \bar{a}$ (nothingness), suñnata (emptiness), animittā (signless). ${ }^{106}$ All four of these characteristics of the cetovimutti are identical in that they connote a state or condition of nonattachment. They also point beyond themselves to a reality beyond definition, a reality that can be known but not in the way that people ordinarily know. The whole thrust of Buddhist meditation, therefore, is to produce a condition of consciousness in which ultimate reality can be known directly, just as objects are perceived directly in the phenomenal world. The Buddhist way of coming to know ultimate reality is to produce a condition of being in which reality can be perceived directly. It is because the

104 The Further Dialogues of the Buddha (Majjhima Nikāya), 2 vols., trans. Robert Chalmers (London: Oxford University Press, 1926-1927), 2:280.

105 Ibid.

106 The Majjhima Nikāya, 1:297. 
reality to be known is "other" than that which is ordinarily known that the process of meditation-sati, samädhi, jhāna and upekkhä-is undergone. The cognizing apparatus must be transformed since, indeed, to reach nibbāna involves a total transformation of consciousness and being.

The process of meditation described in the Pāli suttas provides the proper context for a discussion of Buddhist epistemology. Epistemology in Buddhism is basically a soteriological and not a philosophical problem. To understand

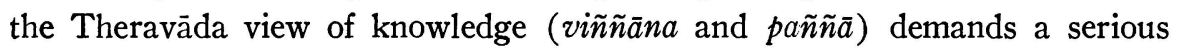
study of the structure of Buddhist meditation. This essay has attempted such a study. It has argued that within the progressive refinement of consciousness developed in the Buddhist meditative process, discriminating and analytical modes of knowledge played a decisive role, both in terms of understanding the true nature of things as well as in producing a state of detachment. It has further argued that meditation leads to a state of consciousness in which only a nondiscriminating mode of knowledge is appropriate. Such knowledge might be labeled mystical or intuitive but, finally, as the texts themselves point out, it is without any proper designation (animittā). 